\title{
ISLAMIC VS CONVENTIONAL FUNDS WITHIN THE FAMILY: SELECTIVITY SKILLS AND MARKET TIMING ABILITY
}

\author{
Anas Ahmad Bani Atta ${ }^{1}$ and Ainulashikin Marzuki ${ }^{2}$ \\ 1 Universiti Sains Islam Malaysia (USIM), Malaysia, baniata_anas@hotmail.com \\ 2 Universiti Sains Islam Malaysia (USIM), Malaysia, ainulashikin@usim.edu.my
}

\begin{abstract}
The aim of this study is to compare the performance of Islamic mutual funds (IMFs) and conventional mutual funds (CMFs) within the same family, and also to examine the performance of fund families in Malaysia over the period 2007 to 2018. The study uses eight measures of performance: raw returns, excess returns, the Sharpe ratio, the Treynor ratio, Jensen's alpha and Carhart's four-factor model as selectivity models, in addition to the Treynor and Mazuy (TM) and Hendrickson and Merton (HM) as market timing models. The study contributes by investigating and comparing performance at the family level. The results show that IMFs exhibited certain fund selection ability over CMFs. However, both types of fund displayed poor market timing ability. At the fund family level, the results show that families exhibited good fund selection skills, but at the same time poor market timing ability. The novel findings of the study relate to the difference in performance between Islamic and conventional funds; shrank compared to the results of previous studies. Due to the common advantages offered by the families for both types of funds. The findings are important for investors because the results provide new evidence about fund family performance. Most investors follow the top-down approach, whereby mutual fund investors initially choose fund families before deciding which specific funds to hold. In addition, the results are important for managers to decide which types of funds that should perform well in the future they could include to their own families.
\end{abstract}

Keywords : Islamic finance, Islamic mutual fund, Fund family, Family performance. JEL Classification: G11; G12; G14; G23; G41.

\author{
Article history: \\ Received : September 16, 2019 \\ Revised : December 2, 2019 \\ Accepted : April 22, 2020 \\ Available online : May 20, 2020 \\ https://doi.org/10.21098/jimf.v6i2.1091
}




\section{INTRODUCTION}

\subsection{Background}

The global assets under management (AUM) value of the mutual fund industry in 2017 was approximately USD 79.2 trillion, which represented a 12\% growth from the USD 71 trillion in 2016, and is expected to continue to grow in the future. The Global Asset Management Report (2018) forecast that global AUM would triple in value by 2025. Mutual funds are an investment vehicle available in many countries across the world. They are essentially an investment basket that pools funds from investors and allocates them into various securities, typically capital and money market instruments. Mutual funds offer a distinct advantage over retail investment, as they afford the individual investor the opportunity to invest in a diversified basket of securities without the burden of information collection, administration, or other costs (Ahmad et al., 2017).

One of the emerging types of mutual fund are Islamic mutual funds (IMFs). In recent years, they have steadily gained in importance in the Islamic financial sector. A report released by the Dubai Islamic Bank (2016) stated that the total value of the global Islamic financial services sector would increase from USD 2.143 trillion in 2015 to USD 2.293 trillion in 2016. It also asserted that the industry could potentially grow by 10 percent annually and forecast that its value by 2020 would reach between USD 3.151 trillion and USD 4.57 trillion. Islamic finance relates to investment or financial activities that comply with Sharia rulings, freeing the market from Islamically-illegal elements or activities and founding it on strong ethical principles (Bani Atta \& Marzuki, 2019a). The foundations of modern Islamic finance were in savings institutions. Two prominent pioneers were the Mit-Ghamr Islamic Saving Associations (MGISA) in Egypt and the Pilgrims Fund Corporation (PFC) in Malaysia (Bani Atta \& Marzuki, 2019b).

The worldwide AUM of IMFs has witnessed a dramatic increase over the past decade. The Malaysia International Islamic Finance Marketplace (MIFC, 2017) reported that in 2008, only 802 funds, totalling AUM of USD 47 billion, were circulating in the global finance market. Almost a decade later, in 2017, the number of these funds had grown to 1,535, with an AUM of USD 70.8 billion. Equity funds make up almost half of these IMFs. The second and third largest are fixed income and real estate and private equity funds, each constituting 17 and $12 \%$ of the total respectively. IMFs are traded in all major global financial markets, including those in Europe, North America, Asia Pacific, the Middle East, and North Africa (GIFR, 2016). Non-Muslims also invest in IMFs, realising that the funds are established on ethical mores and principles and invested in only socially-responsible securities. Non-Muslims are thus enticed to invest in the funds as they consider them to be a part of socially-responsible investment (SRI) funds, while religious investors prefer IMFs as they value ethics in pursuing their investments (Mughal et al., 2017).

An asset management company that manages several mutual funds is called a fund family . Typically, fund families offer numerous types of mutual funds, all of which are marketed under a common brand name and through common marketing and distribution channels (Bhojraj et al., 2011). Most mutual funds in the market are part of fund families. There are at least three reasons why this practice is prevalent (Cici et al., 2018). First, the family structure promotes economies of scale for the member funds' distribution, servicing, and promotion. Second, the 
fund family, in contrast to standalone funds, can easily reallocate its resources among its members in response to market opportunities. Third, the reputation of a family can provide assurance to investors about the capability of the investment managers in selecting and monitoring securities. Members of a fund family cannot be treated like standalone funds.

The prevalence of fund families underlies the motivation this study. Investigating the performance of member funds makes it possible to identify wellperforming funds and then to determine which among them are star funds. The type of fund, whether Islamic or conventional, leading the family may also be distinguished. Because fund families manage a range of funds, each with their respective strategies, measuring the overall performance of the family is altogether a different matter (Gaspar \& Massa, 2006). Pertinent to the investment decisions of the fund are the attributes of the fund family and the reputation of the fund family manager. Good reputation based on the positive performance of member funds is valuable, because it signals the skills of the managers (Adrianto et al., 2019). Therefore, this paper addresses the issue of whether fund families can outperform market benchmarks.

Malaysia is one of the largest markets for Islamic financial services. Initially starting with only two funds in the 1990s, the IMF industry in Malaysia has expanded considerably to 150 funds in 2009, with total AUM of USD 12 billion. Less than a decade later, in Q1 2017, the number of funds had doubled to 388, amassing AUM of USD 22.6 billion. Previous studies have investigated and compared the performance of IMFs and CMFs (Abdullah et al., 2007; Duggimpudi et al., 2010; Tan, 2015; Marzuki \& Worthington, 2015; Hoepner et al., 2013; Marzuki \& Worthington, 2017; Arifin, 2018). However, they have treated mutual funds as standalones, not as members of a family. As previously stated, most mutual funds are part of a fund family. To the authors' knowledge, little research has compared the performance of member funds belonging to the same family and examined performance at the fund family level. This paper thus attempts to close that gap, by comparing the performance of members of a given fund family, as well as examining the overall performance of the family.

The importance of the study is threefold. First, while the literature on fund performance is comprehensive, most of it assumes mutual funds to be standalones, ignoring the fact that they are usually a member of a fund family. Second, though the Islamic financial sector has been developing at a rapid pace, empirical research on the topic, especially the subject discussed in this paper, has remained limited. Third, because Malaysia has been selected as the sample, it is possible to extrapolate the results to the global IMF industry. This is because Malaysia, relative to the global IMF market, currently houses the largest number of IMFs and holds the second-largest IMF assets.

\subsection{Objective}

The objectives of this paper are to compare the performance of IMFs and CMFs belonging to the same family and to investigate the overall performance of fund families in Malaysia from 2007 to 2018. Because Malaysia has the highest share of IMFs globally, the results van be generalised to the international IMF industry. 
Previous studies in Malaysia have concluded that the IMF industry can grow even more rapidly.

In this paper, we address the following two questions:

Q1. Do IMFs under- or overperform CMFs within the same family?

Q2. Do fund families under- or overperform market benchmarks?

The study uses Malaysian IMF and CMF data from 2007 to 2018 to answer these questions.

The remainder of this paper is organised as follows. Section 2 is a review of the literature, while Section 3 presents the methodology used to achieve the objectives. Section 4 discusses the results and analyses them, and Section 5 concludes and offers some relevant recommendations.

\section{LITERATURE REVIEW}

\subsection{Background Theory}

The performance of funds and fund families is directly related to the two important issues of return and risk; these are of great interest to both managers and investors, and theories and models are built on their basis. The issues in this study are closely related to modern portfolio theory, and to a lesser extent to behavioural finance theory. These two theories will be explained in the following sections.

\subsubsection{Modern Portfolio Theory}

Early literature only employed raw returns to measure portfolio performance, and only measured returns when examining mutual fund performance (e.g. Cowles, 1933; Friend et al. 1962). In examining mutual fund performance, these studies ignored the potential risk. Modern portfolio theory began its development in the work of Harry Markowitz (Elton \& Gruber, 1997: p1744 ), who provided an explanation of how, under uncertainty, rational investors would select their portfolios (Markowitz, 1952). He introduced a new portfolio selection hypothesis that challenged the conventional one. Conventional theory posits that the maximisation of returns can be achieved through the diversification of assets that provide the highest expected return. As a response to this model, Markowitz argued that portfolio variance attributed to the variability of return; therefore, to reduce risks, an investor should avoid securities with high covariance. He emphasised the importance of the co-movement of each asset in a given portfolio. Markowitz's mean-variance framework was able to prove that a well diversified portfolio comprised a collection of low covariance level securities. Risk-averse investors, he claimed, should create a portfolio that offered the lowest variance, given a level of return, or the best return, given a level of variance.

\section{a. Stock selection models}

The efficiency of a fund in selecting outperforming stocks is measured using various models. The efficient selection of such stocks enables funds to achieve higher gains at lower risk. Sharpe (1966), Treynor and Mazuy (1966), and Jensen (1968) suggested models that could aid accurate stock selection and achieve 
diversification efficiency. To obtain the Sharpe ratio, the risk-free rate is subtracted from a fund's excess returns, and the ensuing result is divided by the returns' standard deviation. The higher the ratio, the better the performance of the fund relative to the risk, and vice versa. Treynor (1965) improved this model by changing the standard deviation into the systematic risk, or beta, value. He explained the essentiality of using a relevant benchmark to evaluate the performance of a fund. As with the Sharpe ratio, the higher the value of a Treynor ratio, the better the performance of a fund relative to the benchmark.

These scholars were followed by Jensen (1968), who developed a risk-adjusted model for stock selection. He argued that Sharpe's and Treynor's ratios were built on relativity. That is to say, both models compared the performance of a fund to another, even if both were in fact not performing well. As a solution, Jensen presented a model that used a standard absolute measure of performance. While his model is based on the CAPM, he substituted the expected returns for actual realised returns. The result of this equation is in the form of alpha; a positive, significant alpha denotes that the fund in question is outperforming the benchmark. The positive relation between funds and market returns is depicted by a positive, high beta value. Jensen criticises the variability in defining risk in both Sharpe's and Treynor's models, since the former uses standard deviation and the latter beta.

Through the examination of the characteristics of common stock portfolios listed on the NYSE, Fama and Macbeth (1973) established a linear relationship between risk and return, the former coming in two forms: systematic and unsystematic. Book-to-market value and stock holding size to explain returns. Fama and French (1993) investigated 25 stock portfolios from 1963 to 1991 and found that the three-factor model, which includes stock size and book-to-market value, added explanatory power to portfolio returns. Despite the positive results, they added that this model also suffered from another anomaly, namely the continuation of short-term returns. In Banz's (1981) study, size was found to be negatively related to returns, indicating that stocks with high capitalisation generated lower returns. Stocks with higher risk and expected returns had a high earning-to-price ratio. On the contrary, the book-to-market ratio relates positively to average returns (Stattman, 1980; Rosenberg et al., 1985). Finally, Carhart (1997) improved Fama and French's three-factor model by adding the one year momentum factor, with reference to two previous studies (Jegadeesh \& Titman, 1993; DeBondt \& Thaler, 1985). All of these models will be shown as equations in the methodology section.

\section{b. Market Timing Models}

Market timing models illustrate the ability of fund managers to move from one asset class to another at an appropriate time in order to yield gains, and avoid losses, for the fund. An important model for market timing was introduced by Treynor and Mazuy (1966). The TM model depicts a quadratic nonlinear relation between funds and market returns. Treynor and Mazuy believed that investors who successfully forecast market returns would hold a higher proportion of the market portfolio when the market return was high, and vice versa, leading to the nonlinear relationship. 
Henriksson and Merton (1981) introduced another market timing model, claiming that the TM model may be more quality in its approach. In the HM model, a dummy variable separates the positive and negative market returns. Equilibrium theory for market timing, they asserted, was derived from a binary prediction: stock is either predicted to outperform bonds, or vice versa.

\subsubsection{Behavioural Finance Theory}

Behavioural finance attempts to explain the behaviour of financial market players vis-à-vis the effects of psychological factors, and how these factors may lead to their decision making in the market. It offers a scientific explanation which rebuts market efficiency. It attempts to do this by substituting conventional behaviour assumptions with models that integrate the systematic, observable human dimension. Bias among investors is brought about primarily by their humanistic proclivity for overconfidence, and secondly by their desire to avoid future regrets (Barber et al., 1999). This is relevant to this study, since IMF investors do not focus only on achieving good returns, but there is also a psychological factor (for example, a religious factor).

Gilovich (2010) defined behavioural finance as behavioural economics, and asserted that the field was born from the interweaving of economics and psychology, with the purpose of investigating the underlying psychological reasons behind the financial decisions of an investor. Meanwhile, Shefrin and Statman (2000) defined the science as "a rapidly growing area that deals with the influence of psychology on the behavior of financial practitioners". Another definition of behavioural finance was proposed by Sewell (2007). Rational Expectations theory is based on quantitative models such as the Modern Portfolio Theory (MPT), Capital Asset Pricing Model (CAPM) and Arbitrage Pricing Theory (APT). These theories have yet to be confirmed in investment data, in spite of the substantial number of studies conducted on the subject (Barberis \& Thaler, 2003). They maintain that the traditional framework is insufficient in explaining even basic facts concerning individual trading behaviour, cross-section average returns, and the aggregate stock market. In response to this apparent weakness of the traditional paradigm, behavioural finance began to surface, which argues against the full rationality assumption proposed by the traditional view.

Behavioural finance has three main building blocks. The first of these are the limits to arbitrage, the second psychology, and the third sociology (Shiller, 2003). Daniel Kahneman and Amos Tversky are considered to be the fathers of behavioural finance. Kahnneman and Tversky began collaborating in the 1970s. Their initial step was to create more real-life scenarios for psychological experiments on decision theory. They distinguished between normative solutions and real-life subjective responses in their experiments. Both of these academicians' individual research strands ultimately meet at a common point (Heukelom, 2007). "Belief in the Law of Small Numbers", their first published paper, suggests that the law of chance is greatly misunderstood (Tversky \& Kahneman, 1971).

Theirsecond article, "SubjectiveProbability:AJudgmentof Representativeness", discussed biases in representativeness. It was followed up by "On the Psychology of Prediction", which asserted the significant role of representativeness in an 
individual's institutive predictions (Kahneman \& Tversky, 1972, 1973). One of their more prominent works, "Judgment under Uncertainty: Heuristics and Biases" proposes three heuristics: representativeness, availability, and anchoring. They maintained that during times of uncertainty, better judgment and decision making could be achieved by understanding these heuristics and the biases relating to each of them. Their most important work, "Prospect Theory: An Analysis of Decision under Risk", was published in 1979. In this paper, Kahneman and Tversky proposed prospect theory.

\subsection{Previous Studies}

\section{a. Comparison of the Performance of IMFs and CMFs}

Mutual fund investment has been dramatically growing in the developed and emerging markets. The estimation of fund performance is a process part of investment management, which involves feedback to investors for decisionmaking purposes. The issue of performance estimates, or examination of whether managers are able to add value for investors, is related to market efficiency. Funds' excess returns are of interest to both the proponents and opponents of efficient market theory.

Markowitz (1952), Treynor (1965), Sharpe (1966), Jensen (1968), and Fama (1972) contributed considerably to modern portfolio theory. Led by the capital asset pricing model, numerous studies have examined the capability of mutual funds to consistently surpass their benchmarks and achieve abnormal performance. Other important studies, such as those of Malkiel (1995) and Carhart (1997), provide evidence that supports EMH theory. They purport that investment managers have poor skills in predicting the movement of the market and security prices, thus failing to overperform the market in the long-term. Any incidences of when they do outperform the market can be attributed to luck (Treynor \& Mazuy, 1966; Jensen, 1968). Other studies contradict this stance, maintaining that managers consistently outperform the market (Ippolito, 1989; Zhang, 1999; Wermers, 2000). Some research suggests that while managers have poor market timing performance, they do normally have selectivity ability (Carhart 1997; Henriksson, 1984; Jain \& Wu 2000; Elton et al., 2003).

In a study of Indian mutual funds from 2000 to 2009, Duggimpudi et al. (2010) found that well-diversified funds manage to outperform the market. A contradictory result was obtained by Białkowski \& Otten (2011) in Poland. Their Carhart four-factor model analysis suggested that mutual funds in the country did not outperform the market. In an examination of open-end mutual fund performance across 27 countries, Ferreira et al. (2012) found that overall such funds underperform the market. Additionally, they discovered that the determinants of fund performance differed between the USA and other world markets. In East Asia, Ahmad and Nor (2015) found that the real returns of four pension funds were negative. In addition, Tan (2015) found that Taiwanese fund managers were skilled in portfolio selection, as shown by the stellar performance of fifteen equity funds in the domestic market.

The performance of IMFs is determined by values such as attitudes, perceptions, and beliefs. Managers of IMFs allocate their assets in accordance 
with the expectations of investors and not for wealth maximisation. Compared to CMFs, empirical research on IMFs is fairly limited and studies on IMF performance typically use market indices as a benchmark. The use of either a conventional or Islamic index as a benchmark produces mixed results, as the indices show few differences in performance and offer similar diversification and risk benefits (Hakim \& Rashidian, 2004; Girard \& Hassan, 2005).

Using Jensen's alpha, the Sharpe index, and timing and selectivity ability, Abdullah et al. (2007) estimated the performance of both IMFs and CMFs in Malaysia. Their findings suggest that the performance of each type of fund correlates to market trends. IMFs perform better than CMFs in a bearish market, but in a bullish market, the opposite is true. These findings are supported by Merdad et al. (2010). In their estimation of the risk-return behaviour of CMFs and IMFs in Saudi Arabia, they found that IMFs performed worse than CMFs in a bullish market, and vice versa. Studying the risk-return characteristics of 145 IMFs using the Treynor and Mazuy model and CAPM, Hayat and Kraeussl (2011) found that their performance was inferior to Islamic and conventional benchmarks . Additionally, fund managers demonstrated poor timing capability. On the other hand, Agussalim et al. (2017), based on the Sharpe index and return levels, found that IMFs performed worse than CMFs.

In a study of the investment styles and performance of 265 Islamic equity funds across 20 countries, Hoepner et al. (2013) found that only mutual funds traded in large Islamic financial centres, such as the GCC and Malaysia, outperformed international equity benchmarks. Those traded in less developed markets, however, underperformed the benchmarks. Although the permissible investments of IMFs are much more limited than CMFs, they are still able to maintain their efficiency and outpace international benchmarks (Rubio et al., 2012). Rubio et al. arrived at this conclusion after analysing the potential portfolio efficiency losses of 42,340 American funds, 2,614 international funds, and 142 Islamic funds using data envelopment analysis (DEA) and non-parametric measurements of efficiency.

In a study of 131 IMFs and 317 CMFs in Malaysia, Boo et al. (2017) found that IMFs did not display absolute superior performance over CMFs. Nonetheless, they show better performance during financial crises. Boo et al. concluded that IMFs implemented better risk management than CMFs.

To summarise, the performance of IMFs is not necessarily better than market benchmarks. Several studies have maintained that IMFs do not outperform their benchmarks, and that their managers exhibit poor selectivity and timing skills (Abderrezak 2008; Abdullah et al. 2007; Hayat \& Kraeussl 2011). Other studies claim that IMFs have no absolute superiority over CMFs in terms of performance (Hoepner et al. 2009; Agusssalim et al. 2017). Many of these studies, however, consider funds as standalones. Our study, on the other hand, compares the performance of funds belonging to the same family.

\section{b. Performance of Fund Families}

Managers of funds that belong to a fund family may share information and resources with each other, such as research and development (R\&D) and technology. Fund families provide managers with a number of features that can assist them. 
Because such a family comprises several funds with varying strategies, the overall performance of the family is altogether a different matter. A fund family offers different types of funds to cater to the specific objectives of each investor, allowing them to diversify their investments within the same family. An increasing amount of research has been conducted to investigate fund families' role in determining the attributes of their members.

Massa (2003) examined how fund families play a role in determining betweenfund competition through either category proliferation or fund strategies. Fund heterogeneity correlates with between-fund competition between and within families. After examining more than 18,000 US mutual funds from 1992 to 2000, Massa found that the category proliferation strategy positively correlated with fund differentiation. However, no relationship was found between the proliferation strategy and fund performance, indicating that a fund was independent of its within-family peers. The family role in defining a strategy to issue new funds is explained further by Khorana and Servaes (1999). Employing a sample of 1163 new funds, they discovered that these funds were more likely to be introduced by families with higher excess returns. This means that families tend to first improve their reputation through high-return funds before introducing new ones. Family size and experience also positively relate with the issuance of new funds, hence small and less experienced families are less likely to introduce new funds.

Fund family performance also affects their constituents. Analysing US funds, Guedj and Papastaikoudi (2004) discovered the persistent performance of member funds within their families. This persistent excess performance is linked to the number of funds in the family, which can be interpreted as a measure of autonomy that the family exercises in allocating resources unevenly among its members. This finding is congruent with the view that families allocate resources to their members based on their performance, not their needs. This result is supported by Gaspar and Massa (2006), who investigated whether fund families strategically transferred performance to members that were more likely to improve the family's overall return. To do this, they used a sample of US funds from 1991 to 2001. They found that high value funds, that is funds with high fees or historically good performers, achieved their superior performance at the expense of low value funds. These results highlight how the family organisation generates distortions in delegated asset management.

Clare et al. (2014) employed a sample of US and European mutual funds from 1999 to 2009 to investigate the competitive and strategic behaviours of family funds and to establish whether both factors determined risk-taking and performance persistence. They found no evidence to support superior performance persistence of family funds compared to non-family ones. Moreover, based on their historical performance, there was a significant difference between the future performance of family and non-family fund portfolios. There was also compelling evidence that the mid-year ranking of a fund within its own family and sector influenced its risktaking for the remainder of the year.

Fang et al. (2014) determined the strategies conducted by fund families to coordinate their fund managers by investigating the relationship between managerial placement strategies and market efficiency. 1,869 US mutual funds over the period 1991-2010 were employed as the sample. Fang et al. found that 
fund families tended to assign highly-skilled managers to less efficient funds, in the belief that that such managers had the capability to turn the funds around. Fund families thus intervene into managers' duties, and these interventions have the apparent purpose of enhancing the overall value of the family instead of maximising investors' investment value. Cici et al. (2018) examined "how the efficiency of trading desks operated by mutual fund families affected the portfolio performance and investment behaviour of affiliated funds in the US. Their results showed that by operating more efficient trading desks, trading costs could be reduced, and fund families could then significantly improve the performance of their funds and enable them to trade more and hold less liquid portfolios." Aleemi et al. (2019) examined the effects of fund sizes, mainly the induction of new funds and the increase in existing funds, as managed by fund families in their AUM of the mutual fund industry of Pakistan. Their main findings suggest that both existing and new fund sizes have a positive and significant impact on AUM. Additionally, fund growth is strongly associated with family growth.

We conclude therefore that there is a clear gap in the studies of fund performance at the fund family level. Previous studies have focused only on the fund level and the characteristics of fund families, in addition to investigating the impact of these characteristics on fund performance.

\section{METHODOLOGY}

\subsection{Data}

The study sample comprised 170 funds, 88 of them IMFs, distributed amongst 20 families. The data employed included the rate of return, total assets, and market index prices collected from the Bloomberg database, which provides information on mutual funds and also offers data in the form of media and news. These include the Islamic finance platform, with provision of comprehensive data on IMFs and other Islamic instruments, giving an Islamic window that provides data on a range of Islamic financial institutions. The data series are from January 2007 to December 2018.

Similar to previous studies on Malaysian mutual funds, this study used the rate of return on a 3-month Malaysian Treasury bill rate as a proxy for a risk-free rate, collected from Bank Negara Malaysia (Lai \& Lau, 2010; Marzuki, 2015). The study used the monthly fund return data to estimate the beta of each fund. The monthly market return was calculated based on the FSTE All-World. In addition to using the Kuala Lumpur Sharia index (KLSI) as proxies for market returns, the data were collected from Data Stream.

\subsection{Method}

To answer the two research questions, eight performance measures divided into two groups were employed: security selection models, and timing ability models. The seven measures were used to compare the performance of IMFs and CMFs and also to examine the performance of fund families. 


\subsubsection{Security Selection Model}

Stock selection models are also known as risk adjusted measures, raw returns, excess returns, the Sharpe ratio, Treynor ratio, Jensen's alpha, and the Carhart four-factor model.

\section{a. Raw returns and excess returns}

Put simply, raw returns are the returns for each fund; in terms of families, they are the weighted average of raw returns of all funds in the family . Brown and Wu (2012) calculated the performance of families as the average of the information ratio of all funds in the same family.

$$
\text { Raw returns } \text { fam }, t=\sum_{i=1}^{n} W_{i} * \text { Raw returs } \text { r }_{i}
$$

where Raw returns fam, $_{\text {t }}$ are the raw returns for the family, and $\mathrm{W}_{-} \mathrm{i}$ is the weight of fund i calculated by its TNA divided by the TNA of the family. $\mathrm{N}$ is the number of funds in the family. Excess returns are measured using the following equation:

$$
\text { Excess returns }_{i, t}=R_{i, t}-R_{f, t}
$$

where $R_{i, t}$ are the raw returns of fund i over period $\mathrm{t}$, and $R_{f, t}$ is the risk-free rate of return over period t. Excess returns for fund families are measured using the following equation:

$$
\text { Excess returns } s_{\text {fam }, t}=R_{f a m, t}-R_{f, t}
$$

where $R_{\text {fam, }}$ are the raw returns of the family over period $\mathrm{t}$, calculated using equation (3).

\section{b. Sharpe ratio (1966)}

Sharpe (1966) introduced a ratio to rank mutual fund performance by deducting the risk-free rate from fund family returns, divided by the standard deviation of fund returns:

$$
\text { Sharpe }_{i, t}=\frac{R_{i, t}-R_{f, t}}{\sigma_{i, t}}
$$

where $R_{i, t}$ "is the mean return of fund i over period $\mathrm{t}$, and $R_{f, t}$ is the risk-free rate of return over period t. $\sigma_{i, t}$ is the standard deviation of fund i mean excess returns. The Sharpe ratio is widely used as a measure to rank mutual fund performance, especially in recent mutual fund performance studies. The ratio for fund families is measured using the following" equation:

$$
\text { Sharpe }_{\text {fam }, t}=\frac{R_{f a m, t}-R_{f, t}}{\sigma_{f a m, t}}
$$

where $R_{\text {fam, }}$ is the mean return of the fund family over period $t$ calculated by equation (3), and $\sigma_{f a m, t}$ is the standard deviation of fund family mean excess returns. 


\section{c. Treynor ratio (1965)}

The Treynor (1965) "ratio is similar to that of Sharpe, except that it uses beta as a measure of systematic risk, rather than using standard deviation. The Treynor ratio is calculated after subtracting the risk-free rate from the fund return and dividing it by beta. Beta is considered to be the systematic risk between the fund and the market index. The Treynor model is defined" as:

$$
\text { Treynor }_{i, t}=\frac{R_{i, t}-R_{f, t}}{\beta_{i, t}}
$$

where $R_{i, t}$ is the mean return of fund i over period $\mathrm{t}$, and $R_{f, t}$ is the risk-free rate of return over period t. $\beta_{i, t}$ is the beta coefficient of fund $i$. The Treynor ratio for fund families is measured using the following equation:

$$
\text { Treynor }_{\text {fam }, t}=\frac{R_{f a m, t}-R_{f, t}}{\beta_{f a m, t}}
$$

where $R_{f a m, t}$ is the mean return of the fund family over period $t$, calculated by equation (3), and $\beta_{f a m, t}$ is the beta coefficient for the fund family.

\section{d. Single factor CAPM model (Jensen, 1968)}

Jensen's alpha (1968) is the first risk-adjusted measure of returns used in this section. Jensen explains how to measure risk-adjusted abnormal performance in the market by capturing the abnormal excess returns of a fund using Jensen's alpha.

$$
\text { Jensen }=\text { Return }_{i, t}-\text { Return }_{i, t}=\alpha_{i}+\beta\left(\text { Return }_{m, t}-\operatorname{Return}_{f, t}\right)+\varepsilon_{i, t}
$$

where $R_{i, t}$ "is the return on fund $\mathrm{i} ; R_{f, t}$ is the risk-free rate of return; $R_{m, t}$ is the return on the relative market benchmark; $\beta$ measures the sensitivity between the excess return of the market benchmark and the fund; $\alpha_{i}$ captures any excess returns above the market benchmark, and $\varepsilon_{i, t}$ is the term error. Jensen's alpha measures fund over- or underperformance; if it is positive and significant, then the fund is overperforming, indicating that managers earned extra returns on the fund due to stock selection ability. Jensen's alpha for fund families is measured using the following" equation:

$$
\text { Jensen }=\text { Return }_{f a m, t}-\text { Return }_{f, t}=\alpha_{i}+\beta\left(\text { Return }_{m, t}-\text { Return }_{f, t}\right)+\varepsilon_{f a m, t}
$$

where $R_{f a m, t}$ is the return on the family; $\beta$ measures the sensitivity between the excess return of the market benchmark and the family; $\alpha_{i}$ captures any excess returns above the market benchmark; and $\varepsilon_{i, t}$ is the error term. Jensen's alpha measures fund family over- or underperformance; if it is positive and significant, then the fund family is overperforming, indicating that managers earned extra returns on the family due to stock selection ability. 


\section{e. Carhart four-factor model (1997)}

Carhart (1997) expanded Jensen's alpha, taking into consideration multiple factors. These included the size factor, book-to-market factor, and the momentum factor. The Carhart model is defined as follows:

$$
R_{i, t}-R_{f, t}=\alpha_{i}+\beta_{1}\left(R_{m, t}-R_{f, t}\right)+\beta_{2} S M B_{t}+\beta_{3} H M L_{t}+\beta_{4} M O M_{t}+\varepsilon_{i, t}
$$

where $R_{i, t}$ is the "mean return of fund i over period $\mathrm{t} ; R_{f, t}$ is the risk-free rate of return over period $\mathrm{t}$; and $R_{m, t}$ is the return on the relative market benchmark. $S M B_{t}$ is the difference in return between a small-cap and large-cap portfolio at time $t$, and $H M L_{t}$ is the difference in return between a portfolio of high-book-to-market stock and low-book-to market stock at time t. $\beta_{1}$ measures the sensitivity between the market and the fund - if positive and significant, then the fund is closely associated with market movement; $\beta_{2}$ is a coefficient that measures fund exposure - if positive and significant then the fund is associated with small-capitalization stocks; and $\beta_{3}$ is a coefficient that measures fund exposure - if positive and significant, then the fund family is exposed to high-book-to-market stocks. $\alpha_{i}$ measures selectivity ability; if positive and significant, then the fund has superior stock selection ability." The Carhart four-factor model for fund families is measured using the following equation:

$$
R_{f a m, t}-R_{f, t}=\alpha_{i}+\beta_{1}\left(R_{m, t}-R_{f, t}\right)+\beta_{2} S M B_{t}+\beta_{3} H M L_{t}+\beta_{4} M O M_{t}+\varepsilon_{f a m, t}
$$

where $R_{f a m, t}$ is the mean return of the family over period $t ; R_{f, t}$ is the risk-free rate of return over period $\mathrm{t}$; and $R_{m, t}$ is the return on the relative market benchmark. $\beta_{1}$ measures "the sensitivity between the market and the fund family; if positive and significant, then fund family is closely associated with market movement. $\beta_{2}$ is a coefficient that measures fund family exposure; if positive and significant, then the fund family is associated with small-capitalisation stocks. $\beta_{3}$ a coefficient that also measures fund family exposure; if positive and significant, then the fund family is exposed to high-book-to-market stocks. $\alpha_{i}$ measures selectivity ability; if positive and significant, then the fund family has superior stock" selection ability.

\subsubsection{Market Timing Model}

Market timing is measured using the "Treynor and Mazuy (TM) (1966) and Hendrickson and Merton (HM) (1981) approaches. Market timing models identify fund managers' ability to develop timing strategies to move capital between safe and risky securities, based on whether the market is expected to do well or badly. Overall market conditions determine fund performance but overperforming fund forecast entry and exit" strategies .

\section{a. TM Model (1966)}

The TM model recognizes good market timing funds. The timing is captured by the square of market returns, and the model is as follows: 


$$
T . M=R_{i, t}-R_{f}=\alpha_{i}+\beta_{i} R_{m}-R_{f}+\gamma_{i}\left(R_{m}-R_{f}\right)^{2}+\varepsilon_{i}
$$

where $R_{i, t}$ is the mean return of fund i over period $\mathrm{t} ; R_{f, t}$ is the risk-free rate of return over period $\mathrm{t} ; R_{m, t}$ is the return on the relative market benchmark; $\alpha_{i}$ measures selectivity ability; $R_{m, t}{ }^{2}$ is the squared market returns; and $\gamma_{i, t}$ indicates market timing - if positive and significant, then the funds are successful and exposure to the market is increased when markets are performing well. The TM model for fund families is measured using the following equation:

$$
T . M=R_{f a m, t}-R_{f}=\alpha_{i}+\beta_{i} R_{m}-R_{f}+\gamma_{i}\left(R_{m}-R_{f}\right)^{2}+\varepsilon_{f a m}
$$

where $R_{f a m, t}$ is the mean return of the family over period $t$, and $\gamma_{i, t}$ indicates market timing; if positive and significant, then the fund family is successful and exposure to the market is increased when markets are performingwell.

\section{b. HM Model (1981)}

Hendrickson and Merton (1981) introduced another market timing model, claiming that the TM model may be more quality in its approach. In the HM model, a dummy variable separates the positive and negative market returns:

$$
H M=R_{i, t}-R_{f, t}=\alpha_{i}+\beta_{i} R_{m, t}-R_{f}+\delta_{i}\left(R_{m}-R_{f}\right) D_{t}+\varepsilon_{i}
$$

where $R_{i, t}$ is the mean return of the fund over period $\mathrm{t} ; R_{f, t}$ is the risk-free rate of return over period $\mathrm{t} ; R_{m, t}$ is the return on the relative market benchmark; $\alpha_{i}$ measures selectivity ability; $\delta_{i}$ is the market timing coefficient; $D_{t}$ is a dummy variable that take a value of one if market returns are positive and zero otherwise; and $\varepsilon_{f a m, t}$ is the error term.

$$
H M=R_{\text {fam }, t}-R_{f, t}=\alpha_{i}+\beta_{i} R_{m, t}-R_{f}+\delta_{i}\left(R_{m}-R_{f}\right) D_{t}+\varepsilon_{\text {fam }}
$$

\section{RESULTS AND ANALYSIS}

\subsection{Descriptive Statistics}

Table 1 presents the descriptive statistics of the monthly returns of Islamic and conventional mutual funds, fund families, market benchmarks and other risk factors, from 2007 to 2018. The table also shows that the empirical characteristics of negative skewness, excess kurtosis and non-normality in most portfolio returns are the dominant features of the data.

The mean, median, maximum, minimum, and standard deviation for excess market return can also be seen in the table. Fund returns for IMFs and CMFs, fund families, Std. dev denotes standard deviation. SMB stands for small-minus-big; HML for high-minus-low; and MOM is momentum. 
Table 1.

Descriptive Statistics

\begin{tabular}{lcccccccc}
\hline & IMF & CMF & $\begin{array}{c}\text { KLSI } \\
\text { Islamic }\end{array}$ & $\begin{array}{c}\text { FSTE } \\
\text { World }\end{array}$ & SMB & HML & MOM & $\begin{array}{c}\text { Fund } \\
\text { Family }\end{array}$ \\
\hline Mean & 0.0592 & 0.0544 & 0.0024 & 0.0022 & -0.0803 & 0.0461 & -0.0185 & 0.0773 \\
Median & 0.0401 & 0.0673 & 0.0052 & 0.0055 & 0.1323 & -0.1564 & 0.0020 & 0.0549 \\
Maximum & 0.2321 & 0.3596 & 0.3241 & 0.1172 & 0.1835 & 0.4296 & 0.2093 & 0.5432 \\
Minimum & -0.3374 & -0.2890 & -0.2841 & -0.1997 & -0.4057 & -0.1564 & -0.9254 & -0.2150 \\
Std. Dev & 0.2060 & 0.2645 & 0.0468 & 0.0464 & 0.0789 & 0.2674 & 0.5194 & 0.2368 \\
Skewness & -0.3760 & -0.1134 & -0.4974 & -0.7192 & -12.192 & 16.689 & -46.445 & -14.369 \\
Kurtosis & 55.258 & 46.125 & 59.371 & 21.525 & 78.810 & 114.830 & 215.201 & 58.667 \\
\hline
\end{tabular}

Table 2 shows the Pearson correlation coefficients of each mutual fund and fund family, together with the risk factors; below the correlation coefficients are the p-values for the significance tests of the coefficients. Mutual fund returns indicate low correlation with returns of the Kuala Lumpur Sharia index (KLSI) and FSTE All-World, except for IMF returns, which indicate high correlation with the FSTE returns. Similarly, the market indices closely correlate with each other, with significantly high positive correlation coefficients. In addition, the correlation between the risk factors is relatively low and unlikely to lead to a multicollinearity problem in the OLS regressions.

Table 2.

Correlation Matrix

\begin{tabular}{lcccccccc}
\hline & IMF & CMF & $\begin{array}{c}\text { KLSI } \\
\text { Islamic }\end{array}$ & $\begin{array}{c}\text { FSTE } \\
\text { World }\end{array}$ & SMB & HML & MOM & $\begin{array}{c}\text { Fund } \\
\text { Family }\end{array}$ \\
\hline IMF & 1.000 & & & & & & & \\
CMF & -0.0072 & 1.000 & & & & & & \\
& 0.0432 & & & & & & & \\
KLSI Islamic & 0.1583 & 0.0013 & 1.000 & & & & & \\
& 0.0501 & 0.0884 & & & & & \\
FSTE World & 0.9274 & 0.0375 & 0.5760 & 10.000 & & & \\
& 0.0001 & 0.0000 & 0.0000 & & & & & \\
SMB & 0.0165 & 0.2645 & -0.0239 & 0.1542 & 1.000 & & & \\
& 0.0061 & 0.0052 & 0.0071 & 0.0000 & & & & \\
HML & -0.0138 & 0.0104 & 0.0276 & 0.1294 & 0.0637 & 1.000 & & \\
& 0.0120 & 0.0260 & 0.0019 & 0.0000 & 0.0000 & & & \\
MOM & 0.0126 & 0.0028 & -0.0479 & -0.1654 & -0.0557 & -0.4185 & 1.000 & \\
& 0.0154 & 0.0076 & 0.0000 & 0.0000 & 0.0000 & 0.0000 & & \\
Fund Fami & 0.0243 & 0.0145 & 0.0017 & 0.0336 & 0.0015 & 0.0141 & -0.0161 & 1.000 \\
& 0.1923 & 0.4375 & 0.0523 & 0.0435 & 0.0195 & 0.0289 & 0.0388 & \\
\hline
\end{tabular}




\subsection{Security Selection Model}

This section presents the results of the empirical analysis of the six performance measures used to gauge the performance of IMFs relative to CMFs within the same fund family. These measures were raw returns, excess returns, the Sharpe ratio, the Treynor ratio, one factor model Jensen alpha (CAPM ), and Carhart's four factor model. The same measures were used to gauge the performance of fund families.

\section{a. Raw Returns, Excess Eeturns, The Sharpe Ratio, and The Treynor Ratio}

Table 3 shows the monthly means for raw returns and excess returns; the Sharpe and Treynor ratios for IMFs and CMFs; and the fund families, which include IMFs and CMFs. We compared the performance of mutual fund returns using two indices.

The mean returns for IMFs and CMFs are 0.68 and 0.66 percent per month respectively. However, after taking into account the risk-free rate, the mean excess returns of IMFs remain positive at 0.19 percent per month, but the mean excess returns for CMFs are negative, at -0.16 percent per month. Both the mean returns and mean excess returns for IMFs are higher than the market benchmarks. In contrast, the mean excess returns for CMFs are lower than these benchmarks, as well as those of IMFs, but the mean returns are higher than the benchmarks. Although the IMF returns exceed the market returns, the returns are less volatile. In addition, the beta of the IMFs is lower than that of the CMFs. This gives an initial indicator of the attractiveness of IMFs compared to CMFs, in that IMFs have higher returns but lower risk, both total and systematic. At a fund family level, the mean returns are 0.77 percent per month, and the mean excess returns 0.47 percent per month. Both the mean returns and mean excess returns for fund families are higher than both market benchmarks. In addition, the fund family returns are less volatile and less beta, which could due to the diversification provided by the families.

The Sharpe ratio shows the measurement of mean excess returns compared to the total risk represented by the standard deviation. This measure gives the unit of reward received when taking an extra unit of total risk. The results suggest that investment in IMFs achieved a Sharpe ratio of 2.48 percent per month, which is higher than a comparable investment in CMFs (2.16 percent) or investment in the Malaysian market as a whole. The Treynor ratio indicates the measurement of mean excess returns compared to the systematic risk represented by beta. Similar to the Sharpe ratio, the Treynor ratio shows that IMFs outperformed CMFs, regardless of the benchmarks used. At the family level, the Sharpe ratio is 20.1 percent per month, which is higher than a comparable investment in the Malaysian market. The same results were obtained when compared using the Treynor ratio. This is because of the advantages provided by the families, such as greater flexibility in reallocating and bringing economies of scale to the distribution, servicing, and promotion of funds.

The findings of these basic performance models lead us to conclude that IMFs outperform both the market benchmarks and CMFs when relative performance measures are used. Although such measures are commonly used in practice, and 
the results show that the IMFs outperform, while CMFs underperform, the market benchmarks, the results are similar to those of Abdullah et al. (2007) and Merdad et al. (2010), who indicate that the IMFs outperform than CMFs in bearish market . This could demonstrate that the overall market during the study period was in decline, which can be deduced through the risk of funds; in a declining market IMFs are less risky than CMFs, as shown by the results.

These measures can only be used in ranking funds in relation to their peers, in that they provide no fundamental statistical or economic meaning. Therefore, we provide the results of the single- and multi-factor models in the following sections. These performance models, based on the CAPM, give an estimate of the intercept (alpha), which refers to fund performance in relation to the benchmark return.

Table 3.

Mean Raw Returns, Mean Excess Returns, and Sharpe and Treynor Ratios

\begin{tabular}{|c|c|c|c|c|c|}
\hline & IMF & CMF & KLSI Islamic & FSTE World & Fund Family \\
\hline \multicolumn{6}{|c|}{ Panel A: Mean, mean excess return, and Sharpe ratio } \\
\hline Mean return & 0.0686 & 0.0663 & 0.0032 & 0.0023 & 0.0773 \\
\hline Mean excess return & 0.0190 & -0.0167 & -0.0264 & -0.0273 & 0.0477 \\
\hline Std. Dev & 0.7660 & 0.7724 & 0.8169 & 0.8465 & 0.2368 \\
\hline Sharpe ratio & 0.0248 & 0.0216 & -0.0323 & -0.0322 & 0.2015 \\
\hline \multicolumn{6}{|c|}{ Panel B: Beta and Treynor ratio using FTSE Islamic as benchmark } \\
\hline Beta & 0.2925 & 0.3068 & 1.000 & ---- & 0.0085 \\
\hline Treynor & 0.0648 & 0.0544 & --- & ---- & 56.140 \\
\hline \multicolumn{6}{|c|}{ Panel C: Beta and Treynor ratio using FTSE All World as benchmark } \\
\hline Beta & 0.1026 & 0.3726 & --- & 1.000 & 0.1713 \\
\hline Treynor & 0.1849 & 0.0985 & ---- & ---- & 0.2786 \\
\hline
\end{tabular}

\section{b. One Factor Model (Jensen, 1968)}

Table 4 provides the results for the analysis of performance employing the onefactor model (Jensen, 1968) and using the same two market benchmarks. The fund and family estimates for the period from January 2007 to December 2018, using OLS, all the t-statistics are adjusted for heteroscedasticity and autocorrelation. Alpha indicates the monthly abnormal returns of the funds and families.

As shown, the alpha estimate for IMFs is 0.26 percent per month, which is higher than that of CMFs (0.22 percent). Even though the alphas of both are not significantly different from zero. This signifies that even though IMFs underperform both market benchmarks, they significantly outperform CMFs. The adjusted $\mathrm{R}^{\wedge} 2$ for both funds is from 71 to 82 percent with both market benchmarks. The adjusted $\mathrm{R}^{\wedge} 2$ for CMFs is higher than that of IMFs for both market benchmarks.

This indicates a conventional benchmark bias toward CMFs. The high adjusted $\mathrm{R}^{\wedge} 2$ also indicates that fund managers employ a passive strategy by following the market closely, but are unable to perform well. According to previous studies (Hayat \& Kraeussl, 2011), underperformance may result from expenses and fees. 
At a fund family level, the alpha estimate is 0.48 , which is relatively high, and which confirms the benefits offered by families. Even though the alphas remain significant, the adjusted $\mathrm{R}^{\wedge} 2$ is between 83 and 85 percent for both market benchmarks.

Table 4.

One Factor Model (Jensen, 1968)

\begin{tabular}{ccccccccccc}
\hline & Alpha & $\begin{array}{c}\text { IMF } \\
\text { Beta }\end{array}$ & Adj. $\mathbf{R}^{2}$ & Alpha & $\begin{array}{c}\text { CMF } \\
\text { Beta }\end{array}$ & Adj. $\mathbf{R}^{2}$ & Alpha & $\begin{array}{c}\text { Family } \\
\text { Beta }\end{array}$ & Adj. $\mathbf{R}^{2}$ \\
\hline \multicolumn{10}{c}{ KLSI Islamic as Market benchmark } \\
\hline Coef & 0.0264 & 0.2824 & ---- & 0.0227 & 0.2278 & ---- & 0.4826 & 0.0197 & ---- \\
Std. err & 0.0078 & 0.1181 & 0.71 & 0.0078 & 0.1234 & 0.82 & 0.0050 & 0.0929 & 0.85 \\
P-value & 0.4874 & 0.1181 & ---- & 0.4190 & 0.0649 & --- & 0.4554 & 0.0083 & ---- \\
\hline & & \multicolumn{10}{c}{ FTSE All-World as market benchmark } \\
\hline Coef & 0.0163 & -0.0950 & ---- & 0.0076 & 0.3996 & --- & 0.0528 & 0.1863 & --- \\
Std. err & 0.0078 & 0.1428 & 0.74 & 0.0081 & 0.1490 & 0.75 & 0.0050 & 0.0925 & 0.83 \\
P-value & 0.3670 & 0.0595 & ---- & 0.6127 & 0.0073 & ---- & 0.7351 & 0.5437 & ---- \\
\hline
\end{tabular}

\section{c. Four-Factor Model (Carhart, 1997)}

For the four-factor model, the factor returns are not easily available, so data available at the Fama and French website were used, which itself employs the FTSE All-World database to construct monthly data for model.

Table 5 shows the results of the four-factor model for IMFs, CMFs, and fund families using the FTSE All-World as a market benchmark. As can be seen in the table, the four-factor alpha for IMFs is 0.25 percent and significant, which indicates that on average IMFs are able to outperform the four-factor benchmarks. In addition, the results show that IMFs exhibit a lower risk than CMFs, in that the IMF market beta is 0.56 and that of CMFs 0.61 . These results are similar to those using the one-factor model. On the other hand, the four-factor alpha for CMFs is 0.17 percent and not statistically significant, which means that CMFs are unable to outperform the FTSE All-World benchmarks. At the fund family level, the fourfactor alpha is also relatively high (0.51) and significant, exhibiting lower risk with a market beta of 0.17 percent, which indicates that on average, fund families are able to outperform the four-factor benchmarks.

In terms of size preference, both types of fund prefer small stocks to big ones, given that the SMB factor loading is 0.10 for IMFs and 0.17 for CMFs. However , the SMB factor for IMFs is lower and statistically significant. This is because small size funds are easy to manage. The HML factor for IMFs is -0.14 and for CMFs -0.05, suggesting that both types display a preference for growth-to-value stock, indicating that investors are concerned about long term growth, hoping to achieve good performance in the future. These results are similar to those of Renneboog (2008) and Hoepner et al. (2011). The MOM factor for both types of fund is not significant. In conclusion, the preference of IMFs for smaller caps and lower beta results in their significant outperformance over CMFs and the fourfactor benchmarks. At the fund family level, they also prefer small stocks to large 
ones; the SMB factor is 0.13 percent and significant. Fund families also display a preference for growth-to-value stock, with an HML factor of -0.07 and significant. Finally, for fund families, the MOM factor is not significant.

Table 5.

Carhart's Four Factor Model

\begin{tabular}{cccccccccc}
\hline & Coef & $\begin{array}{c}\text { IMF } \\
\text { Std.err }\end{array}$ & P-value & Coef & $\begin{array}{c}\text { CMF } \\
\text { Std.err }\end{array}$ & P-value & Coef & $\begin{array}{c}\text { Family } \\
\text { Std.err }\end{array}$ & P-value \\
\hline Alpha & 0.2578 & 0.0071 & 0.0000 & 0.1729 & 0.0071 & 0.6619 & 0.5115 & 0.0055 & 0.0007 \\
Market & 0.5604 & 0.0090 & 0.0000 & 0.6111 & 0.0090 & 0.0318 & 0.1754 & 0.0952 & 0.0065 \\
SMB & 0.1060 & 0.0031 & 0.0002 & 0.1788 & 0.0031 & 0.0438 & 0.0130 & 0.0159 & 0.0084 \\
HML & -0.1439 & 0.0030 & 0.0003 & -0.0564 & 0.0030 & 0.0164 & -0.0758 & 0.0182 & 0.0377 \\
MOM & 0.1068 & 0.0022 & 0.3930 & 0.1544 & 0.0022 & 0.3200 & 0.0411 & 0.0943 & 0.6628 \\
Adj. $\mathrm{R}^{2}$ & ---- & 0.97 & ---- & ---- & 0.75 & ---- & ---- & 0.82 & --- \\
\hline
\end{tabular}

\subsection{Market Timing Model}

\section{a. Treynor-Mazuy (TM) Model}

Table 6 present the results from the analysis of security selection and market timing ability using the TM and ordinary least squares (OLS),for IMFs, CMFs, and fund families. All the t-statistics were adjusted for heteroscedasticity and autocorrelation. Table 6 shows that both IMFs and CMFs exhibit security selection and market timing coefficients insignificantly different from zero, irrespective of the benchmarks used. Nevertheless, there is evidence that IMFs have better security selection but poorer market timing ability than CMFs. At the fund family level, they also appear to have poor market timing ability, irrespective of the benchmarks used, with gamma indicating such ability. These results are similar to those of Hoepner et al. (2013) and Boo et al. (2017).

Table 6.

Market Timing Measure; Treynor-Mazuy Model

\begin{tabular}{|c|c|c|c|c|c|c|c|c|c|}
\hline & Coef & $\begin{array}{l}\text { IMF } \\
\text { Std.err }\end{array}$ & P-value & Coef & $\begin{array}{l}\text { CMF } \\
\text { Std.err }\end{array}$ & P-value & Coef & $\begin{array}{l}\text { Family } \\
\text { Std.err }\end{array}$ & P-value \\
\hline \multicolumn{10}{|c|}{ KLSI Islamic as market benchmark } \\
\hline Alpha & 0.0282 & 0.0079 & 0.0003 & -0.0476 & 0.0083 & 0.0001 & 0.0510 & 0.005 & 0.0008 \\
\hline Gamma & -0.2446 & 0.3606 & 0.4975 & -0.6534 & 0.3767 & 0.5828 & -0.752 & 0.387 & 0.0652 \\
\hline Adj. $R^{2}$ & --- & 0.83 & --- & --- & 0.85 & --- & --- & 0.86 & --- \\
\hline \multicolumn{10}{|c|}{ FTSE All-World as market benchmark } \\
\hline Alpha & 0.0183 & 0.0079 & 0.0203 & -0.0475 & 0.0082 & 0.0009 & 0.053 & 0.005 & 0.0006 \\
\hline Gamma & -0.0897 & 0.5294 & 0.5588 & -0.1595 & 0.5956 & 0.9234 & -0.773 & 0.593 & 0.4350 \\
\hline Adj. $R^{2}$ & ---- & 0.84 & --- & --- & 0.81 & --- & --- & 0.89 & --- \\
\hline
\end{tabular}




\section{b. Hendrickson -Merton (HM) Model}

Table 7 present the results from the analysis of security selection and market timing ability using the HM model and ordinary least squares (OLS) for IMFs, CMFs, and fund families. All the t-statistics were adjusted for heteroscedasticity and autocorrelation. Table 7 shows that both IMFs and CMFs exhibit security selection and market timing coefficients insignificantly different from zero, irrespective of the benchmarks used. The results are consistent with those in Table 6 based on the TM model. At the fund family level, similar to the results in Table 6, fund families also appear to have poor market timing ability, irrespective of the benchmarks used, with delta indicating timing ability. These results are similar to those of Abderrezak (2008), Abdullah et al. (2007) and Hayat and Kraeussl (2011).

Table 7

Market Timing Measure; Hendrickson-Merton Model

\begin{tabular}{ccccccccccc}
\hline & Coef & $\begin{array}{c}\text { IMF } \\
\text { Std.err }\end{array}$ & P-value & Coef & $\begin{array}{c}\text { CMF } \\
\text { Std.err }\end{array}$ & P-value & Coef & $\begin{array}{c}\text { Family } \\
\text { Std.err }\end{array}$ & P-value \\
\hline \multicolumn{7}{c}{ KLSI Islamic as } & market benchmark \\
\hline Alpha & 0.0257 & 0.0079 & 0.0012 & -0.0461 & 0.0083 & 0.0003 & 0.0501 & 0.005 & 0.0007 \\
Delta & -0.0593 & 0.2297 & 0.7961 & -0.2873 & 0.2400 & -0.207 & -0.207 & 0.169 & 0.2206 \\
Adj. R ${ }^{2}$ & ---- & 0.82 & ---- & ---- & 0.92 & ---- & --- & 0.81 & ---- \\
\hline \multicolumn{10}{c}{ FTSE All-World as market benchmark } \\
\hline Alpha & 0.0200 & 0.0083 & 0.0163 & -0.0443 & 0.0087 & 0.0003 & 0.053 & 0.006 & 0.0003 \\
Delta & -0.4675 & 0.3673 & 0.2030 & -0.4108 & 0.3833 & 0.2838 & -0.022 & 0.238 & 0.9265 \\
Adj. $\mathrm{R}^{2}$ & ---- & 0.85 & ---- & --- & 0.85 & ---- & ---- & 0.80 & --- \\
\hline
\end{tabular}

\section{CONCLUSION AND RECOMMENDATIONS}

\subsection{Conclusion}

The objective of this study was to compare IMF and CMF performance within the same family, and to investigate its performance in Malaysia over the period 2007 to 2018. The study used seven measures of performance, divided into two categories; first, fund selection skills included five measures, raw and excess returns, the Sharp ratio, Treynor ratio, Jensen's alpha, and the Carhart four-factor model. Second, market timing ability included two measures, the Treynor-Mazuy and Henriksson -Merton models.

The results show that IMFs exhibited some fund selection ability over CMFs, which is in contrast to some previous findings (Abdullah et al. 2007; Nainggolan, 2011). The justification of these results is possibly the fact that IMFs have passed their learning phase and their performance is now better than that of CMFs. However, both types of fund displayed poor market timing ability. This could be because during the sample period the market was in decline, as concluded by the risk that showed in the results. According to Abdullah et al. (2007), IMFs perform better during a bear market.

The novel finding provided by the study relates the difference in performance between Islamic and conventional funds shrank compared to the results of 
previous studies. This can be explained by the fact that there was friction and effects between the funds within the same family, which led to the convergence of performance between the types of fund belonging to the same families. In addition, at the fund family level, the results show that they exhibited good fund selection skills, due to the benefits of fund families, such as diversification and more investment opportunities. At the same time, fund families continued to exhibit poor market timing ability.

The findings are important to investors, because the results provide new evidence about fund family performance. Most investors follow the top-down approach, whereby mutual fund investors initially choose fund families before deciding which specific funds to hold. In addition, the results are important for managers to help them decide which types of funds to include in their own families so that they may perform well in the future. The study is also important because it provides participants with an overview of IMF and CMF performance concurrently. Moreover, to the best of our knowledge, the data used in this study are more recent and comprehensive than those in previous literature.

\subsection{Recommendations}

From the results of the study, three recommendations need to be take into consideration. First, due to limited evidence about performance at the fund family level, it is important to increase the focus on this level, because the advantages of fund families may lead to improved performance. In relation to this, it is also highly recommended to extend the focus to the characteristics of the families and their effect on fund performance. Second, Islamic mutual funds can play an important role in social finance, so academics and researchers are recommended to extend the study to other countries, such as Saudi Arabia and Indonesia, which have a large number of Islamic funds. Third, the study recommends the regulator, practitioners to focus more on IMFs and Islamic investment.

\section{REFERENCES}

Abdullah, F., Hassan, T., \& Mohamad, S. (2007). Investigation of Performance of Malaysian Islamic Unit Trust Funds. Managerial Finance, 33(2), 142-153.

Adrianto, F., Chen, E.-T., \& How, J. C. Y. (2019). Spillover Effects in SRI Fund Families. SSRN Electronic Journal, 3311876.

Agussalim, M., Limakrisna, N., \& Ali, H. (2017). Mutual Funds Performance: Conventional and Sharia Product. International Journal of Economics and Financial Issues, 7(4), 150-156.

Ahmad, A., Atta, B., \& Marzuki, A. (2019). The Impact of Funds and Fund Family Characteristics on Fund Performance: Evidence from Malaysia. Journal of Wealth Management E Financial Planning, 6(June), 3-23.

Ahmad, Y., Sun, G., \& Khidmat, W. Bin. (2017). Fund-specific Determinants of Performance: An Empirical Study of Islamic and Conventional Mutual Funds of Pakistan. International Journal of Economics and Financial Issues, 7(5), 359-370. Ahmad, Z., \& Nor, E. (2015). Pension Fund Performance in East Asia: A Comparative Study. Eurasian Journal of Economics and Finance, 3(2), 42-61. 
Aleemi, A. R., Tariq, M., \& Zeeshan, M. (2019). Funds Induction, Flows and Family Growth: The Dynamics of Asset Management Companies. Forthcoming in Pakistan Business Review, 20(4).

Bani Atta, A. A. B., \& Marzuki, A. (2019). The Determinants of Islamic Mutual Fund Flows: Evidence From Malaysia. International Journal of Advanced Research in Economics and Finance, 1(1), 10-21.

Banz, R. W. (1981). The Relationship between Return and Market Value of Common Stocks. Journal of Financial Economics, 9(1), 3-18.

Barber, B. M., Odean, T., Klein, P., Leland, H., Lyons, R., Modest, D., Trueman, B. (1999). The Courage of Misguided Convictions: The Trading Behavior of Individual Investors. Financial Analysts Journal, 41-55.

Barberis, N., \& Thaler, R. H. (2003). A Survey of Behavioral Finance. In Handbook of the Economics of Finance (pp. 1053-1128).

Belsky, G., \& Gilovich, T. (2010). Why Smart People Make Big Money Mistakes and How To Correct Them: Lessons From The Life-Changing Science Of Behavioral Economics.

Bhojraj, S., Jun Cho, Y., \& Yehuda, N. (2011). Mutual Fund Family Size and Mutual Fund Performance: The Role of Regulatory Changes. Journal of Accounting Research, 50(3), 647-684.

Białkowski, J., \& Otten, R. (2011). Emerging Market Mutual Fund Performance: Evidence for Poland. North American Journal of Economics and Finance, 22(2), 118-130.

Brown, D. P., \& Wu, Y. (2012). Mutual Fund Families and Performance Evaluation. Working Paper, University of Wisconsin-Madison,.

Carhart, M. M. (1997). On Persistence in Mutual Fund Performance. The Journal of Finance, 52(1), 57-82.

Cici, G., Dahm, L. K., \& Kempf, A. (2018). Trading Efficiency of Fund Families: Impact on Fund Performance and Investment Behavior. Journal of Banking and Finance, 88, 1-14.

Clare, A., O'Sullivan, N., \& Sherman, M. (2014). Family Status and Mutual Fund Performance. Journal of Asset Management, 15(3), 163-175.

Cowles 3rd, A. (1933). Can Stock Market Forecasters Forecast? Econometrica: Journal of the Econometric Society, 1(3), 309-324.

DeBondt, W., \& Thaler, R. (1985). Does the Stock Market Overreact? Journal of Finance, 40(3), 793-805.

Dubai Islamic Bank (2016). Overview of the Global Islamic Finance Industry.

Duggimpudi, R. R., Abdou, H. A., \& Zaki, M. (2010). An Evaluation of Equity Diversified Mutual Funds: The Case of The Indian Market. Investment Management and Financial Innovations, 7(4), 77-84.

Elton, E. J., \& Gruber, M. J. (1997). Modern Portfolio Theory, 1950 to date. Journal of Banking \& Finance, 21(11-12), 1743-1759.

Elton, E. J., Gruber, M. J., \& Blake, C. R. (2003). Incentive Fees and Mutual Funds, LVIII(2).

Fages, R., Beardsley, B., Brömstrup, I., Donnadieu, H., Macé, B., Pardasani, N., Xu, Q. (2018). Global Asset Management 2018: The Digital Metamorphosis.

Fama, E. F. (1972). Components of Investment Performance. American Finance Association, 27(3), 551-567. 
Fama, E. F., \& French, K. R. (1993). Common Risk Factors in The Returns on Stocks and Bonds. Journal of Financial Economics, 33(1), 3-56.

Fama, E. F., \& Macbeth, J. D. (1973). Risk, Return, and Equilibrium : Empirical Tests. The Journal of Political Economy, 81(3), 607-636.

Fang, L. H., Peress, J., \& Zheng, L. (2014). Does Media Coverage of Stocks Affect Mutual Funds' Trading and Performance? Review of Financial Studies, 27(12), 3441-3466.

Gaspar, J., \& Massa, M. (2006). Favoritism in Mutual Fund Families ? Evidence on Strategic Cross-Fund Subsidization. The Journal of Finance, LXI(0), 0-41.

Girard, E., \& Hassan, M. K. (2005). Faith-based investing--The case of Dow Jones Islamic Indices reexamined. University of New Orleans Working Paper, New Orleans, LA.

Guedj, I., \& Papastaikoudi, J. (2004). Can Mutual Fund Families Affect the Performance of Their Funds? SSRN, (August 2003).

Hakim, S., \& Rashidian, M. (2004). Risk and Return of Islamic Market Indexes. In Makalah Seminar di Malaysia.

Hayat, R., \& Kraeussl, R. (2011). Risk and Return Characteristics of Islamic Equity Funds. Emerging Markets Review, 12(2), 189-203.

Henriksson, R. D. (1984). Market Timing and Mutual Fund Performance : An Empirical Investigation. The Journal of Business, 57(1), 73-96.

Henriksson, R. D., \& Merton, R. C. (1981). On Market Timing and Investment Performance. IL . Statistical Procedures for Evaluating Forecasting Skills. Journal of Business, 54(4), 513-533.

Heukelom, F. (2007). Kahneman and Tversky and the Origin of Behavioral Economics. Tinbergen Institute Discussion Paper, 1-25.

Hoepner, A. G. F., Rammal, H. G., \& Rezec, M. (2013). Islamic Mutual Funds' Financial Performance and International Investment Style: Evidence from 20 countries. European Journal of Finance, 17(9-10), 829-850.

Ippolito, R. A. (1989). Efficiency with Costly Information: A Study of Mutual Fund Performance, 1965-1984. The Quarterly Review of Economics and Finance, 108(1), 1-32.

J., D. W., Friend, I., Brown, F. E., Herman, E. S., \& Vickers, D. (1962). A Study of Mutual Funds. Journal of the American Statistical Association, 58(301), 269.

Jensen, M. C. (1968). The Performance of Mutual Funds in the period 1945-1964. The Journal of Finance, 23(2), 389-416.

Kahneman, D., \& Tversky, A. (1972). Subjective Probability: A Judgment of Representativeness. Cognitive Psychology, 3(3), 430-454.

Khorana, A., \& Servaes, H. (1999). The Determinants of Mutual Fund Starts: Is Real Estate Different?, 12(5), 1043-1074.

Malaysia. World's Islamic Finance Marketplace (MIFC). (2017). Islamic Funds: Gearing Up.

Malkiel, B. G. (1995). Returns from Investing in Equity Mutual Funds 1971 to 1991. The Journal of Finance, 50(2), 549-572.

Markowitz, H. (1952). Portfolio Selection. The Journal of Finance, 7(1), 77-91.

Massa, M. (2003). How Do Family Strategies Affect Fund Performance? When Performance-Maximization Is Not The Only Game in Town. Journal of Financial Economics, 67(2), 249-304. 
Merdad, H., Hassan, M. K., \& Alhenawi, Y. (2010). Islamic Versus Conventional Mutual Funds Performance in Saudi Arabia: A Case Study. JKAU: Islamic Economics, 23(2), 157-193.

Mughal, S. L., Mubeen, M., \& Hanif, M. N. (2017). Funds Flow and Performance of Managed Funds in Pakistan. Archives of Business Research, 5(7), 47-67.

Rosenberg, B., Reid, K., \& Lanstein, R. (1985). Persuasive Evidence of Market Inefficiency. The Journal of Portfolio Management, 11(3), 9-16.

Rubio, J. F., Kabir Hassan, M., \& Jamil Merdad, H. (2012). Non-Parametric Performance Measurement of International and Islamic Mutual Funds. Accounting Research Journal, 25(3), 208-226.

Sewell, M. (2007). Behavioural Finance. In University of Cambridge, (13) 389-393.

Sharpe, W. F. (1966). Mutual Fund Performance. The Journal of Business, 39(1), 119138.

Shefrin, H., \& Statman, M. (2000). Behavioral Portfolio Theory. Journal of Financial and Quantitative Analysis, 35(2), 127-151.

Shiller, R. J. (2003). From Efficient Markets Theory to Behavioral Finance. The Journal of Economic Perspectives, 17(1), 83-104.

Stattman, D. (1980). Book Values and Stock Returns. The Chicago MBA: A Journal of Selected Papers, 4(1), 25-45.

Tan, Ö. F. (2015). Performance of Taiwanese Domestic Equity Funds during Quantitative Easing. Journal of Asian Finance, Economics and Business, 2(4), 5-11.

Treynor and Mazuy. (1966). Can Mutual Funds Outguess the Market? Harvard Business Review, 44(4), 131-136.

Treynor, J. L. (1965). How to Rate Management of Investment Funds. Harvard Business Review, 43(1), 63-75.

Tversky, A., \& Kahneman, D. (1971). Belief in the Law of Small Numbers. Psychological Bulletin, 76(2), 105-110.

Tversky, A., \& Kahneman, D. (1973). Availability: A Heuristic for Judging Frequency and Probability. Cognitive Psychology, 5(1-2), 207-232.

Wermers, R. (2000). Mutual Fund Performance: An Empirical Decomposition into Stock Picking Talent, Style, Transactions Costs, and Expenses. The Journal of Finance, 55(4), 1655-1695.

Zhang. (1999). American Finance Association Is Money Smart? A Study of Mutual Fund Investors ' Fund Selection Ability. The Journal of Finance, 54(3), 901-933. 